\title{
Decision-making and operations in disasters: challenges and opportunities
}






\section{INTRODUCTION}

Around the world, the number of people affected by disasters has increased. Since 2000, nearly 81.7 million people have been affected by disasters globally, with over 1.3 million of reported casualties (CRED 2018). Thesenumbershighlight the need to design and implement efficient and effective disaster management systems, especially considering the limited resourcesavailabletodealwiththem(e.g.SienouandKarduck2012; Nathan et al. 2017). Recent disasters, however, have shown several shortcomings in these systems' performance (Santos-Reyes etal.2010). Amongthesearethedeficient knowledge inemergency response, pooroperational management, absence of leadership, lack of strategies, difficulties toallocate tasks, limited intergovernmental planning, and insufficient coordination (Grünewald et al. 2010; Nigg et al. 2006). To overcome these challenges, there are calls for empirical work to analyse the decision-making structures and public policy in disasters(Holguin-Veras etal.2012;Hartetal.1993).

Even after different articles have explored the implications of decision-making structures in disasters (e.g. Takeda and Helms 2006; Dhouha and Gonzalo 2013; Manyena 2006; Scolobig et al. 2015; Drabek 1985), command and control problems have been identified in several situations (Sienou and Karduck 2012; Van Wassenhove 2006; Whybark et al. 2010). These problems lead to the emergence of ad-hoc norms during disasters (Drabek and McEntire 2003), which affect and are affected by operational activities on the ground. Currently, thelinkandthediscrepancies betweenthedecision-making structureandtheoperationalactivitieson the ground have not been sufficiently researched (Hart et al. 1993).This situation creates the need to look closer to the link between both levels. The purpose is to enhance the performance (i.e. the support provided to disaster victims) achieved by disaster management activities.

Thisarticlecontributestotheunderstanding oftheinteractionofthecomponents ofdisastermanagement responsesystems andtheireffectonlogisticsperformance. Ithasbeenlongthoughtthatthedecision-making structureusedinadisaster management systemhasautomaticimplications onlogisticsperformance (Brouillette andQuarantelli1971).Ithasbeen seenduringdisasteroperationsinsteadthatperformance iscommonly affectedbytheoperationaldecisionsmadeonthe ground(Holguín-Veras etal.2012).Furtherinvestigations are necessarytoanalysetherelationshipbetweenthedecisionmaking structureandoperationalactivitiesonthe groundtoprovideinsightsabouttheirimpactonlogisticsperformance. This articleiscontendingthatitisthe alignmentofbothcomponents whathasaneffectonperformance.

Disastermanagement attheorganisational levelhasbeenstudiedfromtheperspective ofOrganisational Studies (OS)(Mileti andSorensen 1987), whereas operationalactivities on the ground havebeen exploredinthefield of humanitarianlogistics withthesupportofOperationsManagement (OM)(Gupta1995; TaylorandTaylor 2009).EventhoughthelinkbetweenOMandtheorganisational structurehasbeenstatedintheliterature recently (MacCarthyetal.2016), thereisadisconnection betweenbothliteratures.AspartofOS,problemswith centralisedand decentralised systemshavebeenidentifiedbyfocusingontheimpactofthedecision-making structures.Amongthese articles, however, thereislittlediscussionabouttheimportance ofactivitiesonthe ground.Ontheotherhand,different modelsandframeworks havebeendevelopedinOMwiththeaimto improvelogisticsperformance (e.g.Changetal.2007; Tofighietal.2016;Ransikarbum andMason2016). Unfortunately, thesearticlesneglectthevalueofthedecision-making structureandhowitaffectsthemodels developed.Bothperspectives havevaluableinsightstosupportdisasteroperationsand maximiselogistics performance. Thus, agreaterunderstanding oftheelementshinderinglogisticsperformance maybe gainedby blendingtheperspective ofOSandOM.Thisarticlerepresentsasteptowardsuchintegration.

Thecentraldifficultypresentedbytheperspectives undertakeninthefieldsofOSandOMistheassumptionof aprecedence becauseofhierarchy(MiletiandSorensen1987)andurgency(Wijngaardetal.2006), respectively. Thisarticlearguesthat lookingatthedecision-making structureorattheoperationalactivitieson thegroundindependently cancreateadisjointed disastermanagement systemwithanegativeimpacton performance. Instead,FordandSchellenberg(1982)statedthatan organisation canbeassessedbasedonthe extentinwhichthedecision-making structureandtheoperationalactivitiesonthe groundconverge.Takingup thisperspective,thisarticleconsidersthemannerinwhichthealignmentbetweenbothlevelscan beusedto reducetheshortcomings ofeachoneofthem.Hence,thepurposeofthisarticleisnottodeterminewhich perspective should take precedence, but to consider both perspectives and their relation to understand the conditions hindering logistics performance. 


1
2
3
4
5
6
7
8
9

56

50

2

1

2
4

$\begin{array}{ll}5 & 4 \\ 6 & 4\end{array}$

75

8
8
9

$10 \quad 8$

$\begin{array}{ll}11 & 9\end{array}$

$12 \quad 10$

$13 \quad 11$

$14 \quad 12$

$15 \quad 13$

$16 \quad 14$

$17 \quad 15$

$18 \quad 16$

19

20

21

22

23

24

25

26

27

28

29

30

31

32

33

34

35

36

37

$3 \varepsilon$

$3 \subseteq$

40

4

4

4

4

44

45

46

47

48

49

50

5

52

53

54

55

57

58

59

60 
structure, the operational activities on the ground, and their link, are analysed to provide insights to improve disaster management systems. The purposeistotacklethefollowingresearchquestion: Whatistheeffectonlogisticsperformance of thealignment between the operational activities on the ground and the decision-making structure adopted in disaster management? Fromthepractical perspective, thisresearch analyses bothlevelsand thefitbetweenthembased on empirical data to provide insights about the Mexican disaster management system. Real data was gathered to developan analysisthatcouldalsoprovidevaluableresultsforpractitioners (Charlesetal.2016).

This article contributes to practice and research in a variety of ways. First, it increases understanding of the interaction of the components of disaster management response systems and their relationships (i.e. the decision-making structure and the operational activities on the ground). Second, the paper integrates the perspectives ofOSandOM intoaholisticapproachtoimprovedisastermanagement systems. Third,thisarticle proposes a novel perspective to enhance the performance of disaster management systems considering the alignment between the hierarchical decision-making structure and the operational activities on the ground. Finally,thispaperprovidesrecommendationsforbestpracticesin humanitarian logistics whichareapplicableto Mexicoand other countries using centralised decision-making. Thishasthe potential tosupport researchers on OSandOMtodevelopmorecomprehensive solutionsfordisastermanagement.

The paper is organised as follows: Section 2 introduces relevant articles from the perspective of this research and the methodology used is presented in Section 3. Section 4 describes the Mexican framework for disaster management, whereas Section 5 introduces the analysis of the case. Section 6 provides a discussion of the results obtained while Section 7 enumerates some policy implications. Concluding remarks are presented in Section 8 .

\section{LITERATURE REVIEW}

This paper is focused on the link between the decision-making structure and the operational activities on the ground, and its impact on performance of the alignment between them. To place the article in the literature, initially this section introduces the perspective of operational activities on the ground to describe the focus of articles in the area and the importance of logistics performance. Then, the literature on decision-making in disastermanagement organisations is presentedtodefinethemostcommonperspectives usedbeforeinthearea (i.e. centralisation and decentralisation). Next, articles related to performance in disaster management are discussed.Thesesectionserveascontexttoframethefinal sectionlinkingthethreedimensions.

\subsection{Operationalactivitiesontheground}

Humanitarian logistics are essential during disaster management to support affected communities promptly (Nathan etal.2017). This area is closely related to disaster preparedness and response. Caunhye et al. (2012) identified evacuation, facility location, stock pre-positioning, relief distribution, capacity planning, inventory management, and casualty transportation as closely connected activities which have been commonly studied in literature of humanitarian logistics.

Thereareseveralarticlesdeveloping modelsandframeworks toachievesuccessful operations on thefield(See Caunhye etal.2012), even incorporating "social cost” in theperformance measures (SeeHolguín-Veras etal. 2013).Usually,operationalactivitiesonthegroundareperformedinlinewithpolicyandprocedures(Hartetal. 1993), although many times urgency becomes a factor causing inconsistency (Wijngaard et al. 2006). The reason is because of the inconsistencies between plans and the operational environment (Nathan et al. 2017). Despite the importance of decision-making structures and hierarchy between units (Wijngaard et al. 2006), however, most of the articles in the field of humanitarian logistics are neglecting to incorporate these dimensions.

\subsection{Decision-making in disaster management organisations}

The organisational design is relevant because the fit within the internal components of the system, as well as the fit between the system and the environment have a significant effect on performance (Ruffini et al. 2000; Dalton et al. 1980; Ford and Schellenberg 1982). The process and structures involved in decision-making are key dimensions in the organisational structure (Al-Abbadi 2015). These play an important role in the efficiency of organisations because they affect the kind of problems faced in operations. For instance, in a decentralised system, resource constraints can create divisiveness among groups, something less likely to happen on 
centralised systems. On the other hand, in decentralized systems, decision-making has to go through fewer layers of authority allowing more responsiveness, unlike centralised systems (Takeda and Helms 2006).

There has been a considerable discussion about the appropriateness of centralisation and decentralization in the business sector (Dalton et al. 1980). Encouraging the rationalisation of decision-making with inclusion of few individuals leads to centralisation, whereas promoting wider participation in decision-making leads to decentralisation (Marks 1978). The former has several layers of managers, whereas the latter has fewer layers and several decisions are made in parallel. Marks (1978) and Dalton et al. (1980) provided evidence that decentralization can be highly efficient and effective in the business environment, although Dalton et al. (1980) also argued that a decentralised system needs more time for coordination and the resolution of conflicts. Furthermore, they stated that many studies supporting decentralization were not using "hard" performance measures, constraining the value of the results.

Duringdisastermanagement, theoverarching goalofsurvivaloftenleadsgovernments toimplement centralised decisionmaking to attempt to control and find optimal solutions (Child 1972; Quarantelli 1988). That is the reason most emergency management systems are modelled using this approach (Takeda and Helms 2006). In the literature, Takeda and Helms (2006) discuss the use of bureaucratic models for emergency response and identify centralised decisionmaking, external knowledge, complex conditions of the disaster and lack of flexibility as major issues for the bureaucratic model. Dhouha and Gonzalo (2013) study the impact of centralisation of decision-making during the reconstruction stage using a case from the 2003 flood in Tunisia. Their results showed that the top-down approach achieved a poor level of satisfaction.

Centralisation hasbeenconsidered abad modelfordisasters because ofitsinherent disadvantages (Quarantelli

1988). The large number of organisations that require access to the disaster management system (Child 1972; Boinand Lagadec2000; Holguin-Veras etal.2012), theneedforflexibilityintheimplementation ofpolicyand regulation (Oloruntoba 2005), and the need of non-programmable responses (Boin and Lagadec 2000) are reasons why humanitarian organisations are moving their supplychain towards decentralisation (Charles etal.

2016). Manyena (2006) focused on local authorities to explore the link between disaster management and disaster resilience. The author emphasises autonomy for decision-making, fiscal and administrative issues, and anappropriate organisational structureasrelevantelementstobuildresilience.ChangSeng(2013)describesthe disaster preparedness of a decentralized system in an Early Warning System in Indonesia. They identified national security and social conflict, challenges of implementing decentralization policies, funding and resourcesasthemainbarriersforinstitutional advancement indisasterriskreduction.

In view of the evidence against centralisation, Scolobig et al. (2015) argue that a people-centred approach could be more suitable for modern conditions given the limitations in capability of a single organisation, such as the government. Similarly, Kovacs and Spens (2011) mentioned the value of community-based approaches to integrate beneficiaries in activities. Nevertheless, these approaches have been more commonly adopted under improvised circumstances, such as during Hurricane Sandy. The reason is that decentralized models can be complex (Manyena 2006) and very challenging to implement in the context of some countries (Chang Seng 2013). Garschagen (2016) argue that decentralising disaster management in a centralised system, such as a government, faces several challenges for implementation because of the lack of investment in capacity building and procedural adjustment. Furthermore, decentralization may cause lack of standardization and fragmentation if it is not properly prepared and managed (Thomas E. Drabek 1985), a major concern for disaster operations.

Therefore, the major decision-making structures in the literature (Garschagen 2016) have shown several shortcomings at the level of the operational activities on the ground. The current discussion in the field, however,is stillnotintegratingthisdimension.

\subsection{Pertormance in disaster management systems}

Looking at organisational performance, Santos-Reyes et al. (2010) proposed a fault-tree model to assess the organisational activities of the government during disasters in Mexico. Later on, Roshan Bhakta et al. (201 ) provided an analysis of the performance of fire services organisations in emergency conditions in New $\mathrm{Z}^{-}$and. The authors confirmed that stability, leadership, stakeholder communication and adaptability are ma; . predictors of organisational success in those settings. Dube et al. (2016) studied countries affected by man-made disasters with a high State Fragility Index (http://fundforpeace.org/fsi/) to explore the motivation and impact of host governments in the performance of International Humanitarian Organisations (IHOs). The authors 


1
55
50

2

2
3
4
5
6
7
8
9

1

2

3

4

5

6

7

8

8
9

10

11

12

13

14

15

16

17

18

19

20

21

22

23

24

25

26

27

28

29

30

31

32

33

34

35

36

37

38

39

40

41

42

43

44

45

46

47

48

49

54

56

57

58

59

60 
nflicting strategic goals and enforcement capabilities.

There are extensive studies measuring performance in the supply chain (Beamon 1999; Helena 2007). The purpose of the operational activities on the ground is to satisfy the requirements of the victims (Thomas and Mizushima 2005). Considering the high stakes involved in disaster operations (Kovacs and Spens 2011), this paper defineslogistics performance as the ability to successfully satisfy such needs. Beamon (1999) classified supply chain performance measuresinthreemaintypes:resources, outputandflexibility. Resourcesaccountfor the input of a process, whereas output involvestheorganisation's and customers' goals, andflexibilityrefersto the capability to adapt to fluctuations (Beamon 1999). The successful achievement of these three measures is linked to the satisfaction of the needs of disaster victims. The reason logistics performance is studied in this article is the focus on the support to disaster victims. Operational activities on the ground are performed bya large number of actors such as: host (governments with responsibility over the affected areas) and associated governments, regional authorities, State governments, military units, NGOs, private and quasi-private organisations (Cozzolino 2012; Mileti and Sorensen 1987). Instead of looking to the performance of individual organisations (i.e. the supplyside), this research is focused on the ability of the disaster management systemto satisfy the requirements of the victims (i.e. the demand side). This support is linked to the three types of measures describedbyBeamon(1999).

Focusing on logistics performance, Thompson (2015) assessed the current state of disaster logistics in the Caribbean through eight in-depth unstructured interviews with logistics managers and heads of disaster agencies. They identified a lack of a coherent and integrated logistics strategy as a common problem. Nigg et al. (2006) provided an assessment of governmental activities focused on evacuation and providing shelters and temporary housing after Katrina in the United States. The authors identified several issues in terms of shelter management, lack of policies for successful evacuation across states, poor standardisation and disjointed local political cultures.

\subsection{The decision-making structure and logistics performance}

The research presented so far provides context about operational activities on the ground, decision-making structures and performance in disaster management. This section includes sources looking at thelinkbetween these dimensions.

In view of the variety of organisations involved in disaster management, research has considered different types of organisations. Some studies analyse Non-Governmental Organisations (NGOs) during disaster operations to improve their supply chain (Kumar et al. 2009), propose an integrated framework for post-disaster reconstruction ( $\mathrm{Lu}$ and $\mathrm{Xu}$ 2015), determine the location of facilities and the amount to stock to preposition based on decentralisation policies from Red Cross (Charles et al. 2016), and analyse the role of the organisational structure of NGOs in their influence on policy development (Marquez 2016). Additionally, other authors have looked at the link between NGO's organisational principles and performance (Hilhorst and Schmiemann 2002) and thus provided insights about the challenges for logistics in these organisations (Kovacs and Spens 2009).

In many countries, the military provides primary assistance in cases of disaster because of its structure and the resources it has available (Cozzolino 2012; Heaslip and Barber 2014). Heaslip and Barber (2014) focus on the organisational challenges of the military for disaster operations and how the interaction between coordination, logistics and human resources can improve performance in disaster operations.

Despite the importance of the NGOs and the military, the role of the host government as initiators of disaster response is prominent. These governments have the jurisdiction and authority to allow operations to be carried out (Cozzolino 2012), and they become responsible for disaster operations abiding by a set of national and international regulations (Dube et al. 2016). Therefore, the decision-making structure of the host government affects the overall performance of disaster operations (Brouillette and Quarantelli 1971) and its activities on the ground are the reference point for the disaster management system. From that perspective, Westley et al. (2008) performed an analysis of bureaucracy based on FEMA following Katrina in the United States. The authors pointed out failures associated to the provision of relief and care to the people affected because of the highly centralised institutional system which hindered participation of more people in the decision process. 
Chandes andPaché(2010)proposed theuseofadaptivecollective strategies toimprove humanitarian logistics. Theyuseda case in Peru to show the potential benefits of collective action. Using participant observation, they analysed the governmental response and found the importance of acentral directive unit, with the purpose of coordinating the multiple civil defence committees. They suggested the inclusion of adapted performance indicators, masscustomization, and collective action to improve humanitarian operations. Richter et al. (2013) proposed a decentralized evacuation application on mobile devices for situations in which a centralised systems has failed or is non-existent. Using agent-based simulation to test the peer-to-peer information communication, the authors showed how a decentralised approach can provide advantages to improve evacuation management.

In the literature presented we find that there is evidence of the assessment of different systems based on an organisational view or a logistics perspective, but the fit between them has been neglected before. The aim of this article is to fill that gap by taking a holistic approach to analyse the impact of misalignment between those levels on performance during emergencies.

\section{METHODOLOGY \\ 3.1. Overall design}

In order to analyse the impact of the alignment between the decision-making structure and operational activities on the ground, this study includes a case based on the activities of the Mexican disaster management system during the worst disaster experienced in thirty years. Given the exploratory nature of the research question (What is the effect on logistics performance of the alignment between the operational activities on the ground andthedecision-makingstructure adopted in disastermanagement?), acase study approachusing empirical data wasundertaken to analyse the situation in its naturalcontext(Vossetal.2002).

Case studies can be used for theory generation, theory testing or theory elaboration (Ketokivi andChoi 2014) because it is a strategy that allows to understand the dynamics existent within a defined situation (Eisenhardt 1989). This paper is defined as theory elaboration, which is placed in between theory testing and theory generation (KetokiviandChoi2014).FisherandAguinis(2017)definedtheoryelaborationas “....the processof conceptualizing and executing empirical research using pre-existing conceptual ideas or a preliminary model as a basis for developing new theoretical insights bycontrasting, specifying, or structuring theoretical constructs andrelationstoaccountforandexplain empiricalobservations" (FisherandAguinis2017).

A theory can be elaborated through the in-depth analysis of the relationships among different elements considering the general context and previous findings simultaneously (Ketokivi and Choi 2014). Using constructs and relationships from OS and OM, this research empirically analyses the effect on logistics performance of therelation between the decision-making structure and the operational activities on the ground. Thepurposeistoelaborateoncurrent knowledgeandincreasetheunderstanding abouttherelationshipbetween thedecision-making structure andtheoperational activities onthegroundusingempirical data, whichcanlead tothedevelopment ofmoreintegratedsolutions.

\subsection{Researchplanning}

For the development of this research the methodology outlined by Eisenhardt (1989) was followed. Initially, literature from different areas was analysed and used to define the research question. Next, the case was selected considering the vulnerability of developing countries (Davarzani et al.2015) and the research question defined. Then, archival data and interview were selected as data collection methods and data collection was undertaken. After the information was collected, a within-a-case analysis was performed to investigate the relationships between components and theireffect in logistics performance. Next, the results were compared and contrasted withtheextantliteratureandclosurewasreached (Eisenhardt1989).

\subsection{Case selection}

The case study method is one of the most common approaches undertaken in Operations Management studies (Taylor and Taylor 2009) because it can be used to explain complex real-world phenomena (Peter-Christian and Dmitrij 2015). It has been used in this research because it can provide relevant insights about the situation (Helena 2007). Yin (1994) states that case studies should be used when "a why or how question is being asked about a contemporary set of events over which the investigator has little or no control". Case studies can help to understand more deeply the processes and context, and to provide meaningful insights in an underexplored field. 
$56 \quad 51$

2

$\begin{array}{ll}3 & 1 \\ 4 & 2\end{array}$

$\begin{array}{ll}4 & 3 \\ 5 & 4\end{array}$

64

75

$\begin{array}{ll}8 & 6\end{array}$

9

$10 \quad 8$

$11 \quad 9$
12

$12 \quad 10$

$13 \quad 11$

$14 \quad 12$

$15 \quad 13$

$16 \quad 14$

$\begin{array}{ll}17 & 15\end{array}$

$\begin{array}{ll}18 & 16 \\ 19 & 17\end{array}$

$19 \quad 17$

$21 \quad 18$

$22 \quad 19$

$23 \quad 20$

$24 \quad 21$

$25 \quad 22$

$26 \quad 23$

$27 \quad 24$

$28 \quad 25$

$29 \quad 26$

$30 \quad 27$

$\begin{array}{ll}31 & 28 \\ 32 & 29\end{array}$

$33 \quad 29$

$34 \quad 30$

$35 \quad 31$

36

$37 \quad 3$

$38 \quad 35$

$\begin{array}{ll}39 & 36\end{array}$

$\begin{array}{ll}40 & 37\end{array}$

41
42

$43 \quad 39$

$44 \quad 40$

$45-41$

$46 \quad 42$

$47 \quad 43$

$48 \quad 44$

$49 \quad 45$

$50 \quad 46$

$51 \quad 47$

$\begin{array}{ll}52 & 48 \\ 53 & \end{array}$

$54 \quad 49$

$55 \quad 50$

57

58

59 
ructures and public policy in disasters (Holguin-Veras et al. 2012), a case study can be used to capture the conditions generated by the disaster and evaluate the performance of the disaster management system. Davarzani etal.2015 suggestthatitisimportant to understand the impact and performance of the decision-making structure in settings with political and economic uncertainty, such as the conditions experienced in developing countries. Accordingly, acasestudyin Mexico was selected because it fulfils these characteristics. The case was based on the 2007 flooding in Villahermosa.

Mexico is located in a very active seismic area and in the path of hurricanes and tropical storms coming from the Atlantic and the Pacific (Saldana-Zorrilla 2015). From 1950 to 2015, the country has been the most disaster prone nation in the Americas after the United States (CRED 2016). Mexico's case is also interesting because it has the second largest economy in Latin America, while at the same time, nearly half the population lives in poverty conditions (INEGI 2012). Despite having a disaster policy in place, recent experiences have demonstrated that the support provided to disaster victims using a top-down centralised decision-making structure is not achieving the expected results (Santos-Reyes et al. 2010).

Developing countries, such as Mexico, commonly use a 'military' approach for decision-making because it provides a known and manageable structure. Activities can be delegated depending on technical skills and expertise using a centralised model of management involving a single 'leading' organisation (Scolobig et al. 2015). However, it has been pointed out how this approach is focussed more on the process than in the outcome (Takeda and Helms 2006).

The organisational and decision-making structure of the Mexican disaster management system was acquired through a review of Mexican regulations, white papers, and research articles. The operational procedures employed by the Mexican organisations involved in humanitarian logistics in the field included rules and regulations from organisations involved in disaster relief operations, as well as guidelines provided by Plan Marina and Plan DN-III (Disaster management plans for the most serious disasters) from the navy and the military, respectively. Additionally, the emergency relief request process for the Natural Disaster Fund (FONDEN) was analysed along with the process to request medicines in case of emergency.

\subsection{Data collection methods}

Data collection was performed through a combination of interviews and gathering of archival data. Information about medical services and procedures was obtained from an interview with CENAPRECE [National Centre of Preventive Plans and Disease Control (CENAPRECE), personal communication, September 2, 2014], whereas an interview with a representative from the United Nations Office for the Coordination of Humanitarian Affairs (OCHA) was carried out to understand the procedures undertaken by them and other organisations for disaster situations in Mexico [Office for Coordination of Humanitarian Affairs (OCHA), personal communication, August 28, 2014]. Additionally, an exploratory interview was undertaken with members of the disaster management unit from the Mexican National Defence Secretariat (SEDENA) [SEDENA, personal communication, March 11, 2010]. The interview involved a set of written questions answered by the officials prior to the interview, and open-ended questions about general procedures and practices.

Secondary information about the circumstances of the disaster was obtained through a series of freedom of information (FOI) requests directed to relevant Local, State and National government agencies. Participants other than the government were incorporated using reports and press releases from these other organisations. This included the relief aid sent by other governments and international organisations.

The data collected provides insights about the implications of the current system in performance. The database collected included the organisational decision-making structure and the logistics activities performed on the ground in the country. Having both sides is essential to explore the impact of the alignment between them on performance. Therefore, both sides can be analysed to draw conclusions from a holistic perspective, with the purpose of identifying the real challenges affecting performance beyond the common constructs associated with the operational or the organisational view.

\subsection{Dataanalysis}

Data analysis istheleaststandardised part of theapplication of thecase studymethod(Eisenhardt 1989). The data from the interviews and FOI requests was initially used to draw a picture of the logistics activities performed byauthorities duringthedisaster. Based onthat, an analysis of supplyanddemand wascarried out. 
The information about the resources deployed by the organisations was contrasted to the demand of disaster victims based on the operational parameters (i.e. personnel required per activity, service capacity of the products, shelter requirements) provided by the organisations, policy and guidelines publicly available. This sectionoftheanalysiswas clusteredbasedonthelogisticsactivitytoidentifypatternspresentinthecase.

Based on the performance of the logistics activities, the results were analysed from the lens of the decision- making structure usedin Mexicousingthethreetype of metrics described byBeamon (1999). Fromthatpoint onwards, the analysis included the comparison and contrast of the results with extant literature (Eisenhardt 1989) to evaluate the accuracy of considering an OS or OMperspective alone. Then, the alignment between the decisionmaking structure and the operational activities on the ground is investigated, and its effect on logistics performance was analysed.

\section{DISASTER MANAGEMENT IN MEXICO}

\subsection{National Civil Protection System}

Decision-making in disaster situations in Mexico uses a centralised, top-down structure to avoid uncertainty in the control and management of operations (Parnell 2015), with the National System for Civil Protection (SINAPROC) as the coordinating body in charge of develop and oversee plans from different participants for disaster management.

Humanitarian logistics in Mexico basically involves three main activities: the provision of food, shelter and medical attention (Ordaz and Zeballos 2007). These activities are carried out with support from SINAPROC based on the guidelines established as part of the policy.

\subsection{Disaster management structure}

Disaster management in the country includes four main branches: executive coordination, technical coordination, technical support and co-responsibility. SINAPROC works as the coordinator of the different branches to manage emergency situations. Each branch has a different purpose;

- Executive coordination. The Ministry of Interior is the entity responsible for working with organisations of the three government levels (viz. National, State and Municipal).

- Technical coordination. Organisations with the capability and expertise to provide technical counsel for the planning, operation and assessment of activities related to disaster management in any emergency.

- Technical support. Organisations with capabilities to provide aid and advice for a specific disaster.

- Co-responsibility. Organisations charged with the responsibilities to provide supplementary support along with human and material resources to the emergency activities on top of their normal duties.

\subsection{Guidelines for disaster response}

After a disaster strikes a community, the first agency on location should provide aid to the victims, and then municipal authorities have to take over to continue the relief activities. If local authorities can cope with the disaster they oversee the whole operation, otherwise they have to notify state authorities to ask for support. That procedure is repeated for the case of state and federal authorities, until the full resources of SINAPROC are deployed (Ordaz and Zeballos 2007). This approach is consistent with other governmental systems, in which as the disaster develops response structures at local, regional and national level need to be requested to deal with the situation. (Roshan Bhakta et al. 2014).

For initial supplies after an event, authorities in Mexico use stock prepositioning because this strategy can prevent response delays. Mexican authorities use a prepositioning policy for food pantries, whereas for medicines, some kits are stocked at local units, but most of the medicines are available on request after the disaster strikes (SEGOB 2012). Information about the method to determine the level of stock, however, is not clearly defined.

For the ongoing supply of relief, authorities can request relief items based on needs assessment. The level of demand is established by regional authorities to request support and supplies from FONDEN. Consumable goods are arranged in kits to provide support for four people for four days. The rest of the items are provided based on the composition of the population. The products listed in the "Agreement for the operation of the fund for natural disasters" can be charged to FONDEN (SEGOB 2012), using them as standard units for distribution. 


3

3

37

38

39

51

5

5

5

55


reventive Planning and Disease Control, namely CENAPRECE (SEGOB 2012). A council is in charge of evaluating the requests based on the information available about the emergency. In case the request is approved, the items are gathered/procured and sent to the area [National Centre of Preventive Plans and Disease Control (CENAPRECE), personal communication, September 2, 2014].

The relief is sent to communities and facilities supported by authorities. Civil protection authorities must select places in which acceptable living conditions can be provided to disaster victims to serve as shelters prior to any emergency [SEDENA, personal communication, March 11, 2010]. Risk atlases should be developed to graphically show the levels of danger in different regions. Using these atlases, a list of suitable shelters is provided to people before the disaster strikes to ease evacuation procedures and allow them to move to these facilities in cases of emergency (Saldana-Zorrilla 2015).

\section{DISASTER MANAGEMENT IN THE FLOOD OF VILLAHERMOSA IN 2007}

\subsection{Villahermosa, Mexico}

Villahermosa is the county seat of the Municipality of Centro (CENTRO) and the capital of the State of Tabasco. The links of Villahermosa to natural gas production and ports for oil exports make the area economically important for the country. Nonetheless, around $49.6 \%$ of the population are living in poverty (INEGI 2012).

Villahermosa is surrounded by the rivers Grijalva and Carrizales, it borders with the water body "Laguna de los Espejos" and it is close to the "Las Peñitas" dam system, which makes the city an area very prone to flooding. In the absence of a successful relocation policy for the community, disaster management in the area is a priority for the State government.

\subsection{Conditions of the flood of 2007 in Villahermosa}

A severe cold front caused strong rainfall in several parts of the country, especially in Villahermosa. This situation, combined with the opening of the floodgates of the "Peñitas" dam, created a catastrophic event with nearly $80 \%$ of Tabasco covered by water (approximately $19,800 \mathrm{Km}^{2}$ ), with water heights of four meters and more than one million people affected (Santos-Reyes et al. 2010). Around $90 \%$ of the area of Villahermosa was covered by water.

\subsection{Data collected about the flood in Villahermosa}

Most of the data collection was done through FOI requests submitted to national and state authorities using the list of organisations involved in logistics activities during disasters. The list was available from the guidelines for disaster management in the country. A total of 134 requests were directed to eight regional authorities and 128 requests were filed to nine National authorities. Among the seventeen agencies approached, thirteen agencies declared to have participated and were included in the analysis. At regional level the municipality of Centro, family services (DIF), State Health Ministry of Tabasco (STABASCO), Public Security Secretariat (SSP), Social Security Institute of the State of Tabasco (ISSET), Civil Protection (PC) and the Transport and Communications Secretariat (SCT). At National level, information was collected from DICONSA, Social Security Mexican Institute (IMSS), Health Ministry (SMEXICO), SEDENA, Ministry of Interior (SEGOB) and the Navy (SEMAR). Given that large-scale situations require to support local capacity with other sources, relief aid sent by other governments recorded by Mexican authorities was also included.

Concerning operations after the disaster occurred, other organisations were contacted to enquire for reports about their involvement in relief activities. Online reports and press releases were gathered as well. Information about organisations such as the Presbyterian Mission Agency, Action by Churches Together International, Aktion Deutschland Hilft, Samaritan's purse, Malteser, World Vision, and Search and Rescue Assistance in Disasters was obtained, as well as information about the Mexican Red Cross.

The overview of the data collected can be seen in Table 1. The table includes information about the source institution and the official document reference (if applicable). Information collected included emergency facilities used, demand served, relief items pre-positioned, personnel employed, vehicles involved, the variation of demand per period, international aid, and supply capacity from the organisations involved.

Table 1. Data collected about the case of Villahermosa 


\begin{tabular}{|c|c|c|}
\hline Type of data & Source & FOI \\
\hline Shelters used & PC, ISSET & 700106513,06401914 \\
\hline Facility cleaning cost & DIF & 1236000003414 \\
\hline Distribution centres used & SEDENA, DICONSA & 700003414,2015000000714 \\
\hline Procurement per product & DICONSA & R2015000008113 \\
\hline $\begin{array}{l}\text { Required personnel per } \\
\text { activity }\end{array}$ & SEDENA, PC, IMSS, DICONSA & $\begin{array}{l}700003214,00001514,00430914,00432114, \\
64101320214,700004914,2015000010414\end{array}$ \\
\hline $\begin{array}{l}\text { Number of personnel per } \\
\text { activity per organisation }\end{array}$ & $\begin{array}{l}\text { DICONSA, DIF, IMSS, ISSET, PC, } \\
\text { SMEXICO, STABASCO, SCT, SEDENA, } \\
\text { SEGOB, SEMAR, SSP }\end{array}$ & $\begin{array}{l}2015000001314,2015000003814, \\
2015000004014,06399914,0064100438914, \\
06644914,06402614,06402714, \\
0001200006714,06400314,06243714, \\
0000700031014,0000700144314, \\
0000700106513,0000400264914, \text { Press release }\end{array}$ \\
\hline $\begin{array}{l}\text { Total personnel per } \\
\text { agency }\end{array}$ & $\begin{array}{l}\text { DICONSA, DIF, IMSS, ISSET, PC, } \\
\text { SMEXICO, STABASCO, SCT, SEDENA, } \\
\text { SEGOB, SEMAR, SSP }\end{array}$ & $\begin{array}{l}\text { 148/2007, 05924314, } \\
2015000001314,2015000003814, \\
2015000004014,06399914,0064100438914, \\
06644914,06402614,06402714, \\
0001200006714,06400314,06243714, \\
0000700031014,0000700144314, \\
0000700106513,0000400264914, \text { Press release }\end{array}$ \\
\hline Vehicles used & $\begin{array}{l}\text { CENTRO, DICONSA, DIF, IMSS, PC, } \\
\text { SMEXICO, STABASCO, SEDENA, } \\
\text { SEGOB, SEMAR, SSP } \\
\text { SEDENA }\end{array}$ & $\begin{array}{l}\text { 148/2007, 05924314 } \\
\text { 05923014, 05923214, 2015000001014, } \\
2015000003714,2015000003914,06400114 \text {, } \\
0064100439014,0064100439414,06402814, \\
0001200006814,05923814,05924014, \\
0000700002614,0000700031114, \\
0000700031314,0000700106513,\end{array}$ \\
\hline & & 0000400264914, Press release $148 / 2007$ \\
\hline & $-1-1$ & 05924414 \\
\hline Medicines delivered & SEGOB & 0000400160314 \\
\hline Flood mask & CENAPRED & 0413000000214 \\
\hline $\begin{array}{l}\text { Technical reports of the } \\
\text { situation }\end{array}$ & SEMAR, CENAPRED & 0064100439014,0413000000514 \\
\hline & 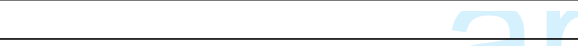 & $\square$ \\
\hline $\begin{array}{l}\text { International aid } \\
\text { Elevation models of the } \\
\text { region }\end{array}$ & $\begin{array}{l}\text { SRE } \\
\text { United States Geological Survey (www.usg } \\
\text { Geography and Statistics (INEGI) in Mexic }\end{array}$ & $\begin{array}{l}0000500088214 \\
\text { gov) and the website of the National Institute of } \\
\text { (http://www.inegi.org.mx/) }\end{array}$ \\
\hline $\begin{array}{l}\text { Road network } \\
\text { Neighbourhoods } \\
\text { denominated Basic Geo- } \\
\text { Statistical Area }\end{array}$ & \multicolumn{2}{|c|}{ 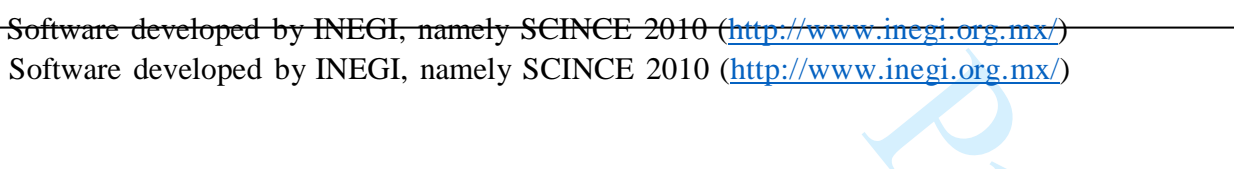 } \\
\hline
\end{tabular}

$\begin{array}{rr}52 & 7 \\ 53 & 8 \\ 54 & 9 \\ 55 & 10 \\ 56 & \end{array}$


developed

by INEGI, namely

SCINCE

2010

(http://ww

w.inegi.or

g.mx/)

Resources

from

NGOs

Online

reports

from the

Mexican

Red Cross,

Presbyteria

n Mission

Agency,

Action by lft, Samaritan's purse, Malteser,

World Vision, Search and Rescue Assistance in Disasters, Medical Teams International, Adventist Development and Relief Agency, Americares and the World Food Programme.

\subsection{Logistics activities in Villahermosa}

Based on the activities considered by Caunhye et al. (2012), the information gathered was used to analyse the operations during the flood in Villahermosa. Unfortunately, there was no information available about casualty transportation, capacity planning, or inventory management, thus the analysis is focused on evacuation, facility location, stock pre-positioning, and relief distribution.

EvacuationandFacilitylocation

Information from Civil Protection, the Social Security Institute of the State of Tabasco and the Mexican National Defence Secretariat showed that around 99,000 people were sheltered during the emergency. The number of evacuees was even higher considering the number of people fleeing the area to stay in other 
$56 \quad 51$

2

$\begin{array}{ll}3 & 1 \\ 4 & 2\end{array}$

53

$\begin{array}{ll}5 & 4\end{array}$

7
8

$8 \quad 6$

$\begin{array}{ll}9 & 7 \\ 10 & 8\end{array}$

119

$12 \quad 10$

$13 \quad 11$

$\begin{array}{ll}14 & 12 \\ 15 & 13\end{array}$

$\begin{array}{ll}15 & 13 \\ 16 & \end{array}$

$17 \quad 14$

$18 \quad 15$

$19 \quad 16$

$20 \quad 17$

$21 \quad 18$

$22 \quad 19$

$23 \quad 20$

$24 \quad 21$

$25 \quad 22$

$26 \quad 23$

$27 \quad 24$

$28 \quad 25$

$29 \quad 26$

$30 \quad 27$

$\begin{array}{ll}31 & 28\end{array}$

32

$33 \quad 29$

$34 \quad 30$

$35 \quad 31$

$36 \quad 32$

$37 \quad 33$

$38 \quad 34$

$39 \quad 35$

$40 \quad 36$

$41 \quad 37$

$42 \quad 38$

$43 \quad 39$

$44 \quad 40$

$45 \quad 41$

$46 \quad 42$

$47 \quad 43$

$48 \quad 44$

$49 \quad 45$

$50 \quad 46$

$51 \quad 47$
$52 \quad 48$

$\begin{array}{ll}52 & 48 \\ 53 & \end{array}$

$54 \quad 49$

$55 \quad 50$

57

58

59 
ortation vehicles, 17 boats and 4 helicopters during the emergency, which considering the capacity of each vehicle and the time horizon of one day, ought to be enough for the evacuation activities.

Before the flood of 2007, the public catalogue of facilities of Villahermosa contained 107 shelters with a total capacity of 26,380 people. The catalogue considered the use of some police stations to provide support for 4-10 people. Those facilities can be arguably appropriate to serve as shelter for disaster victims. Beyond that, the limited capacity of these facilities creates the need to serve several facilities under disaster conditions, which represents a challenge for relief distribution.

Contradicting the evidence that shelters usually are underused (Nigg et al. 2006), there was insufficient capacity in the shelters listed by authorities to accommodate the evacuees. There was a need to improvise, even to the point of using private homes as shelters. The result was the use of around 676 shelters in the area. Shelters declared to have been used by authorities during the emergency were identified and georeferenced in TransCAD® using a layer of the road network available from INEGI.

The results of the analysis agree with reports of facilities flooded and the demand exceeding the capacity provided by the authorities (Santos-Reyes et al. 2010). It is believed than more than one million people affected by the disaster could not find shelters (Santos-Reyes et al. 2010).

Conversely, human resources were exceeding the needs of the situation. From the co-responsibility branch of the disaster management hierarchy in Mexico, there were 13,124 members of staff from 7 organisations for support on shelters, and 3,150 teams (including one doctor, a nurse, a dentist and two helpers) from five organisations for healthcare in shelters as well. The military provided guidelines of six members of shelter staff to serve 90 people for activities such as cooking, security, organising leisure activities, among others, meanwhile it was required to have one healthcare team for every 90 people sheltered. Following those guidelines, it seemed authorities had roughly enough personnel to serve around 196,860 people in terms of shelter care and 283,500 people in terms of healthcare. Considering the estimated demand of 99,000 people, authorities had nearly two and three times the employees required for shelter care and healthcare, respectively. The number of staff in the area was more than that required to serve the highest number of people estimated by National authorities at any point (150,000 people).

Stockprepositioning

DICONSA, organisation in charge of procurement and social programmes, reported a stock of 2,500 prepositioned food pantries available for distribution in the area. In terms of medicines, there was a local supply of medicines from the health authorities (National and State). Distribution of the initial stock was planned to take place right after the disaster giving time to undertake needs assessment. With knowledge about demand, State authorities could request food and medicines from FONDEN and CENAPRECE, respectively.

It is evident that the magnitude of the event exceeded the capacity held by authorities. There were enough items to satisfy a little over $10 \%$ of the population in terms of food, and enough medicine to cover less than $3 \%$ of the population in the first days of the emergency. Because of the magnitude of the event, this is understandable. However, considering the objective of stock prepositioning about reduction of lead time, the process to determine the number and location of stock to preposition is essential. Currently, there is no information about a clear policy to determine the number of stock to preposition other than available budget. For instance, after the flood of Acapulco in 2013, authorities changed from the 2,500 food pantries held before the emergency to 10,000 food pantries for prepositioning (DICONSA 2014), which was around the number of people sheltered in the State during the flood. The stock was subsequently reduced to 5,000 three years after the flood.

In the case, the number of food and medicine prepositioned seemed arbitrary. The number of items was similar to the number kept in other regions of the country, without regard to vulnerability and the demographic composition. Therefore, the prepositioning policy did not provide the expected result of enhancing performance. Moreover, the analysis emphasises the need to determine the number of items to preposition based on an analysis of previous events, the demographic conditions and prospective scenarios.

\section{$\underline{\text { Reliefdistribution }}$}

Mexican authorities deployed large quantities of items to Tabasco using the FONDEN, being the Centro Municipality the main focus of the aid. Water and food were the focus of authorities, although sand bags along with blankets and mattresses were also supplied in large numbers. 
A list of items shipped by authorities obtained from SINAPROC and cross-referenced with information from the MinistryofInterior provided information about demand estimates of National and State authorities, along with the number of items shipped to the Centro Municipality. There were discrepancies between National and State authorities regarding the estimated number of people affected ranging from 22,500 to 367,500 people. Inaccurate estimations show potential for underestimation, but a common problem in reality is overestimation led by a 'false' sense of urgency (Kovacs and Spens 2011). There are some stages in which the estimations of State authorities were more than three times the estimation of National authorities, with a sudden decrease days later. These discrepancies reveal poor information management. Even if only half of the food sent by authorities reached the area, it would be more than twice the food required for people sheltered. Including the relief sent from other organisations, the amount of food provided was considerably more than what was needed. Additionally, lack of information updates was identified, which led to oversupply of some resources (i.e. food) and undersupply of others (i.e. diapers and towels).

Despite all the efforts from the participants, relief distribution became a significant issue as demonstrated by reports of shortages of food (Santos-Reyes et al. 2010), medicines and supplementary items. According to the information, the problem was the shortage of items at the first stage and delays to deliver the relief, which confirms the failure of the stock pre-positioning policy. This partly occurred because of uneven coverage due to political interference (Dudley 2007), impeding the provision of relief to high priority communities.

\subsection{Effect of the fit between the decision-making structure and operational activities on the ground in} logistics performance

The impact of the fit between the decision-making structure and operational activities on the ground in performance is based on three types of measures: resources, output and flexibility (See Beamon 1999).

\section{Resources}

Resources in disaster management include vehicles, relief aid, human resources and facilities, among others. This research shows a significant disagreement between the centralised system and operations in terms of resources. Looking at human resources, the Mexican system works through the activation of different layers, depending on the magnitude of the situation. The purpose is to allow the decision-maker to authorise enough resources to manage the emergency, thereby using resources efficiently. However, the activation of one layer (i.e. local, regional and/or national) means in fact the activation of many organisations, which at the operational level are deployed with the purpose to reach as many people as possible. This was shown in the case, where the healthcare and shelter care needed could have been achieved with fewer organisations. Therefore, the policy to minimise the use of resources at the top of the structure is clearly contradicted at the bottom of the system, allowed by the limited visibility of the decision-maker. The overcrowding of people can be evident for field agents, but it is hardly noticed on the top layers of the hierarchy. The result is convergence of people, which hinders operations by complicating coordination and allowing overlapping activities (Oloruntoba 2005).

Regarding stock prepositioning, the amount of prepositioned stock is set depending on budget, instead of determining the number of items based on other criteria such as vulnerability, previous disasters and the demographic composition of the country. Nevertheless, for the case study this was reflected in a very limited capacity of immediate supply compared to demand, which delayed response and complicated the scenario at the initial stages of the disaster. Hence, this policy was unable to provide insurance of immediate response, which further complicates the successful use of centralised decision-making because of the possibility of slow response (Takeda and Helms 2006).

Facility location is left for co-responsibility branches. However, the central decision-maker needs to oversee this activity better. Shelter location is performed independently from distribution centre location. The former is carried out by civil protection authorities using public facilities, whereas the latter is undertaken by DICONSA based on pre-owned regional facilities. Therefore, decisions are fragmented, which is a contradiction to the centralised system. Focusing on shelters, there are three major issues identified. The first is the absence of risk maps, the second is the use of unsuitable facilities because of the lack of well-defined criteria, and the third is the absence of scenario planning to manage demand. These problems are a result of the disagreement between the decision-making structure and the operational activities on the ground, which had an impact on poor facility location and management. 
2 In disaster management, the perspective of the beneficiaries is essential. A significant aspect affecting the 3 perception of the disaster victims is relief distribution. Distribution becomes a problem in a centralised system 4 because distribution plans ought to be drafted after assessing the state of the infrastructure (Holguin-Veras et al.

5 2012). In view of the multi-layered structure behind a centralised system, drafting the plans and approving them 6 can be very time consuming and therefore unsuitable for disaster operations. There are two strategies embedded 7 in the Mexican system to alleviate this problem; the development of maps of the disaster to draft distribution 8 plans in advanced, and stock prepositioned for immediate deployment to allow for planning time. However, 9 plans based on untested assumptions about the operational environment can affect the success of operations (Nathanetal.2017). That strategy assumes that operational authorities have risk maps and enough prepositioned stock, the latter being arbitrarily determined as discussed previously.

Regarding risk maps, nowadays the National atlas (the repository of risk maps) is still seriously incomplete and local atlases are even in poorer conditions (Alexander 2015). The reasons for this are the lack of archive material, financial resources and human personnel (CONAGUA 2011). Consequently, disaster planning is not based on the analysis of hazard scenarios nor geographical factors (Alexander 2015), incurring a high risk of choosing unsuitable facilities. Therefore, distribution plans at the operational level are indeed drafted after the disaster. The case of Villahermosa provided an example of this problem. The lack of a well-prepared risk atlas prevented authorities from developing distribution plans, which complicated the selection of suitable routes and effective shelter location. The result was the need of improvisation at the operational level and delays in the provision of relief items.

\section{$21 \quad$ Flexibility}

The capacity to react to variations in demand and adapt to different conditions is closely related to information management. Several issues for information management have been identified in centralised systems such as one-way communication (Scolobig et al. 2015), complicated the access to the system (Boin and Lagadec 2000) and the inability to consider external information (Takeda and Helms 2006). In the case presented, information sharing was a challenge that led to poor needs assessment and made centralised decision-making highly inefficient. The centralised approach relies on accurate information filtered through the layers of the hierarchy, but reality showed contradictions in demand estimates between National and State authorities. Independent data gathering and analysis can be useful to get robust results, but poor information sharing makes the effort fruitless.

A centralised system should use few comprehensive information systems (Marks 1978). Conversely, each agency handled its own information without sharing it, which can derive in unreliable data and duplication of efforts. It can be argued then that information management during disasters in Mexico is mostly decentralised, because different data was collected from various agencies and handled independently. This contradiction led to a centralised system with conflicting and incomplete information for decision-making, and operational activities on the ground with decisions based on inaccurate conditions. The result was an inflexible disaster management system with fragmented information.

Also related to flexibility, the case showed infrequent needs assessment update. Because of the work involved in collecting and analysing information for each agency, the time between one assessment and the next could be extended to weeks or even a month. In view of the dynamic conditions of disaster management, that situation prevented the disaster management system to adapt and react to variations effectively.

Overall, this research has identified misalignment between the decision-making structure and operational activities on the ground in terms of information collection and sharing, facility location procedures, the prepositioning policy and distribution planning. The result has been the conflicting use of resources, deficient satisfaction of disaster victims and an inflexible disaster management system affecting logistics performance.

\section{DISCUSSION}

47 The analysis shows poor logistics performance as a result of significant disagreements between centralisation and operations. The first area to consider is to strengthen preparedness and response to support centralisation. The slow response associated with this approach (Takeda and Helms 2006) can be alleviated by placing resources and attention in disaster preparedness. The operational activities on the ground are often more 
concerned with disaster response, but appropriate planning can reduce ambiguity (Wijngaard et al. 2006) and response times. Planning, however, has to include input from different stakeholders at different levels to make the plans useful, achievable and sustainable. This integration relates directly to distribution, facility location and stock prepositioning.

The alignment of goals is another important aspect to bear in mind. In a centralised system, it is expected that the goals from top layers guide the entire system, but in a collaborative environment such as disaster management the goals of different stakeholders, governmental and non-governmental, can affect the result. Logistics performance in the case of Villahermosa was affected by conflicting goals at different levels, even whenthe overarching goalwastopreventdeathandsuffering.Insteadofhavingtheoperationalactivitiesonthe ground working within the boundaries established by the top layers of hierarchy, the objectives and guidelines needtobeproperlyagreedacross participantstohaveconsistentoperations.

Information management is an essential area to achieve high logistics performance. The case showed the impact of having a centralised structure without collaborative and reliable information systems. The duplication of efforts and the unreliability of information severely affects decision-making and complicates operational activities on the ground. Therefore, a collaborative and interactive system needs to be developed to support the decision-making structure at the top and to allow communication and the development of robust information to support operational activities on the ground. Mechanisms to aggregate and cross-reference information can help reduce the number of overlaps between different participants and provide a better quality of information to top layers of the disaster management system.

According to the interview with the representative from OCHA, the clarity about the decision-maker in the current system allows them to quickly approach them to offer support. This is an important revelation because even though Mexican authorities are commonly reluctant to ask for external support, when needed, international organisations can promptly provide support for the government, recognising the legitimacy of the authority. This aligns with the view that having a clear strategic centre and collective vision can be beneficial for operations (Chandes and Paché 2010). This view is contradicted, however, by smaller organisations which struggled to get in touch with the government and relevant decision-makers (Hernández 2009). This is expected because in this kind of system there is the possibility of an input overload (Hart et al. 1993). Adding more actors to the system can complicate control even further, which led authorities to ignore less recognised organisations. This is a problem because self-initiated participants are a reality in emergencies, and movements such as occupy Sandy have shown the potential of people-centred initiatives. Therefore, following the findings of Khan and Rahman (2007), a participation and collaboration mechanism that joins community members and different stakeholders can be valuable to improve disaster management in the country considering the centralised decision-making structure. Although working partnerships can emerge from disaster response activities, there is a need to develop agreements and policies in advance for the joint participation between different organisations and the Mexican government. Such agreements can ease coordination, clarify functions and improve overall operations by empowering different organisations and the wider society to work with the government instead of passively following them.

Needs assessment is one of the most important activities in the first hours after disaster (Charles et al. 2016), but the case showed poor management of this activity. Inaccurate needs assessment caused problems such as shortages of relief and uneven distribution. The flow of low-priority products can hinder operations (HolguinVeras et al. 2012), because of the space and resources required. Needs assessment and procurement policies for disaster management should follow reliable and well-planned guidelines for a centralised system to work. These policies should ensure the flow of resources could satisfy different requirements in a timely manner and account for the operational capabilities. Currently that is an area for improvement for the case for Mexico.

Standardisation is one of the key aspects to align centralisation and operational activities on the ground. The case revealed that standardisation of relief items was a significant success for distribution after the initial phase, because it allowed to use more optimally the transportation resources and to make the distribution process more efficient. This idea has to be extrapolated to procedures and guidelines to improve logistics performance. The needs assessment process showed that procedures are not standardised, allowing each organisation to operate under their own terms. This approach created discrepancies among organisations which affected the level of service. For centralised decisions to achieve the expected results, the system has to create the right conditions through proper guidance and support to the operational activities on the ground, which has to be informed by the perspective of different stakeholders. 
The presence of a set of regulations and an organisation overseeing the resources can support the stream of literature developing optimisation models (Caunhye et al. 2012), because models commonly aggregate resources to provide an optimal response, which is in principle better than the sum of optimised responses from each actor. Nevertheless, models have to be robust enough to account of the uncertain conditions of disaster management and the set of unforeseen challenges encountered, combining reliability and responsiveness.

Beyond the measures discussed, there are more alternatives in the literature that can be useful. Investment on disaster management capabilities, as mentioned by Kunz et al. (2014), to improve the flow of resources within the country and from outside, and agility and leanness in humanitarian operations could be approaches to improve responsiveness that can be supported by a centralised system (Cozzolino 2012). On the other hand, flattening the decision-making structure in disaster management would also allow for a speedy response.

Overall, this analysis emphasises the importance of looking at the alignment between the decision-making structure and operational activities on the ground. Instead of approaching the disaster management system from the perspective of the decision-making structure or the operational activities on the ground, the alignment between them has to be considered to enhance performance. This analysis suggests that appropriate alignment between both dimensions can alleviate some of the shortcomings centralisation and improve the performance of the disaster management system. According to this analysis, several of the issues commonly associated to centralisation are due to the misalignment between the decision-making structure and operations. This is a relevant finding because it moves from the current argument about the appropriate decision-making structure for disaster management to the identification of components to implement an efficient and effective disaster management system. It shows that the key for high performance is embedded in the integrated design of the system and the alignment between its components, which can prove a more feasible approach that moving from one decision-making structure to another, especially considering the evidence of problems associated with both approaches.

\section{POLICY IMPLICATIONS}

26

The analysis presented provided a set of implications that are relevant for practice. The implementation of a decision-making structure has to be supported by sensible assumptions at the operational level. This can prevent significant variations between policy and logistics activities.

The use of a centralised decision-making structure in Mexico faces challenges related to responsiveness, information management and poor collaboration. The current response processes are designed to use resources efficiently, but these require gathering, compiling and presenting information to decision-makers on higher layers of the system, thereby increasing response time. That information is not always shared across participants to find a collaborative solution, complicating joint operations. Additionally, distribution is performed by local branches of the government, which can use disaster relief with political purposes. It is important to create an inclusive disaster management system to facilitate operations, prevent delays, allow the participation of unbiased actors, and adapt to the dynamic environment posed by disasters. This requires a revision of disaster management policies and the structure of the disaster management system.

The activation of agencies based on layers of government has to be thoroughly revised. Sending every organisation available to the field is not the solution unless the right resources are at their disposal. In view of the logistics activities performed during disasters, the activation could be linked to the deployment of organisations based on the area of expertise and the needs assessment to prevent congestion and idle participants. Therefore, policy has to be developed to ensure resources are being properly managed and that guidelines are in place to improve operations.

Quality assurance processes for facility location, stock prepositioning and needs assessment have to be properly designed and implemented. This research identified several challenges related to the lack of control and proper management of those activities. Moreover, these quality assurance processes have to be shared across participant organisations to identify shortcomings (such as the lack of risk atlases or the absence of facility selection guidelines) and achieve high performance operations. In that sense, policy about disaster management has to provide guidance for clear boundaries and responsibilities of different participants, with the inclusion of potential self-initiated actors.

\section{CONCLUSIONS}


This paper provided an analysis of the impact of the alignment between centralisation and operations in the activities performed in the flood of Villahermosa in 2007. Data gathered from governmental and nongovernmental organisations was used to look into the logistics operations carried out during the emergency and assess the performance of the disaster management system.

The centralised decision-making structure implemented in Mexico faces challenges of communication and responsiveness, as shown by several challenges arising from the case. The information showed discrepancies in the estimation of victims between State and National authorities, infrequent information updates, and delays on the initial stages of distribution. However, it was found that these problems are not only inherent of the decisionmaking structure, but also a result of the misalignment between centralisation and the operational activities on the ground. This article argues that aligning both dimensions can reduce some of the challenges and enhance logistics performance in a disaster management system. Considering the nature of centralisation, the implementation of investments in disaster capabilities, agility and leanness can help align the decision-making structure and the operational activities on the ground to improve the logistics performance of the system.

Because coordination and collaboration are of paramount importance in disaster management (B. Balcik et al. 2010), these should be strengthened by information sharing and clear agreements about guidelines for operation, to avoid duplication of efforts and uneven coverage. In the case of Villahermosa, the information gathered showed that poor collaboration led to the supply of more than twice the food required. Additionally, uneven coveragetookplace because of politicalreasons and theimprovised facilitiesusedbyauthorities. It is important to adapt the centralised structure to allow dialogue across levels and organisations to provide a more responsive system under uncertain conditions at the operational level. This requires to consider several layers of managers in a centralised system (Christensen and Knudsen 2010) and the potential of introducing better information systems and well-designed operationalproceduresonthegroundtoeasecollaboration.

Generalisation is one of the challenges of the use of case studies. However, several of insights obtained from the case can be extrapolated to other centralised decision-making systems. The analysis was based on logistics activities commonly performed by host governments in disasters as stated by Caunhye et al. (2012), which makes this approach suitable to other similar systems. For instance, the argument about policy and plans based on untested assumptions shows a gap in the disaster management structure that can be found on several developing countries. Therefore, the analysis of the fit between the decision-making structure and operational activities on the ground can deliver interesting results in similar settings. However, there are limitations in terms of the type of disaster management structure, the level of development of the country, the financing structure and the governmental stability that can restrict the generalisation of some practical implications identified.

The analysis of procedures and policy is based on documentation and interviews whereas the logistics performance was assessed using secondary information. Therefore, information from the interviews can be affected by bias or experience, and inaccurate records of the activities during the emergency could affect the data. We tried to avoid those problems by cross-referencing the information and checking accounts from other sources such as newspapers and academic articles, but we reckon information can be a limitation of this research. Furthermore, information about transportation during evacuation and casualty transportation was not available from authorities, complicating the analysis. Finally, the analysis performed is focused on logistics performance based on the activities identified by Caunhye et al. (2012), without considering their link to other emergency activities.

This analysis showed the importance of looking at the alignment of the decision-making structure and the operational activities on the ground to achieve successful operations during disasters. This area can be further benefited by future research using primary information for the assessment of logistics performance, cross-case analysis to identify variations among countries, papers looking at the development of an assessment of logistics performance on a decentralised disaster management system to draw comparisons, and articles discussing the interaction of information management, collaboration agreements and decision-making structures to achieve high performance humanitarian operations.

\section{ACKNOWLEDGEMENTS}

The authors of this paper would like to thank the two anonymous reviewers for their valuable comments, observations and time. Their insights have been essential for shaping this article and any mistakes and/or omissions remain responsibility of the authors alone. 


\section{REFERENCES}

Al-Abbadi, S. A. (2015), "Market Environment and Centralized Decision-Making and Their Impact on the Effectiveness of Organizations", International Business Research, Vol. 8 No. 2, pp. 129142.

Alexander, D. (2015), "Evaluation of civil protection programmes, with a case study from Mexico", Disaster Prevention and Management: An International Journal, Vol. 24 No. 2, pp. 263-283.

Balcik, B., Beamon, B. M., Krejci, C. C., Muramatsu, K. M., \& Ramirez, M. (2010), "Coordination in humanitarian relief chains: Practices, challenges and opportunities", International Journal of Production Economics, Vol. 126 No. 1, pp. 22-34.

Beamon, B. M. (1999), "Measurin suk oly chain performance", International Journal of Operations \& Production Managemen; V V' 19 No. 3/4, pp. 275-292.

Boin, A., \& Lagadec, P. (2000), "Preparing for the Future: Critical Challenges in Crisis Management", Journal of Contingencies \& Crisis Management, Vol. 8 No. 4, pp. 185.

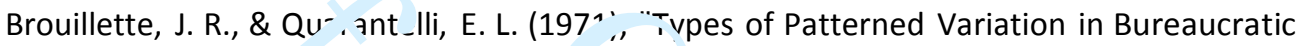
Adaptaticr, to Organizational ,tress", jociological Inquiry, Vol. 41 No. 1, pp. 39-46.

Caunhye, A. M., Nie, X., \& Pokharel, S. '2012' 'Optimization models in emergency logistics: A literature review", Socio-Economic PI .11. ing Sciences, Vol. 46 No. 1, pp. 4-13.

Chandes, J., \& Paché, G. (2010), "Investig- ...1 • „manitarian logistics issues: from operations management to strategic action", Jourr il c Manufacturing Technology Management, Vol. 21 No. 3, pp. 320-340.

Chang, M. S., Tseng, Y. L., \& Chen, J. W. (2007), "A scenario planning approach for the flood emergency logistics preparation problem under uncertainty", Transportation Research Part E: Logistics and Transportation Review, Vol. 43 No. 6, pp. 737-754.

Chang Seng, D. S. (2013), "Tsunami resilience: Multi-level institutional arrangements, architectures and system of governance for disaster risk preparedness in Indonesia", Environmental

Charles, A., Lauras, M., Van Wassenhove, L. N., \& Dupont, L. (2016), "Designing an efficient humanitarian supply network", Journal of Operations Management, Vol. 47-48 No., pp. 5870.

Child, J. (1972), "Organizational Structure, Environment and Performance: The Role of Strategic Choice", Sociology, Vol. 6 No. 1, pp. 1-22.

Christensen, M., \& Knudsen, T. (2010), "Design of Decision-Making Organizations", Management Science, Vol. 56 No. 1, pp. 71-89.

CONAGUA (2011), "Manual para el control de inundaciones", working paper, México,

Cozzolino, A. (2012), Humanitarian logistics : cross-sector cooperation in disaster relief management, Heidelberg.

CRED (2016), Advanced search, Université Catholique de Louvain, available at: http://www.emdat.be/advanced search/index.html.

CRED (2018), Advanced search, Université Catholique de Louvain, available at: http://www.emdat.be/advanced search/index.html.

Dalton, D. R., Todor, W. D., Spendolini, M. J., Fielding, G. J., \& Porter, L. W. (1980), "Organization Structure and Performance: A Critical Review", The Academy of Management Review, Vol. 5 No. 1, pp. 49-64.

Davarzani, H., Zanjirani Farahani, R., \& Rahmandad, H. (2015), "Understanding econo-political risks: Production Management, Vol. 35 No. 11, pp. 1567-1591.

Dhouha, B., \& Gonzalo, L. (2013), "Centralized decision making, users' participation and satisfaction in post-disaster reconstruction: The case of Tunisia", International Journal of Disaster 
Drabek, T. E . 1385$),$ "Managing the Emergency Response", Public Administration Review, Vol. 45 N'J., no. 85-92.

3

4

5

6

7

8

9

10

11

12

13

14

15

16

17

18

19

20

21

22

23

24

25

26

27

28

29

30

31

32

33

34

Drabek, T L., \& McEntire, D. A. (2003), "Emergent phenomena and the sociology of disaster: Le:_ulls rends and opportunities from the research literature", Disaster Prevention and Mañ sem _nt Vol. 12 No. 2, pp. 97-112.

Dube, N., Van aer' dal. T., Teunter, R. H., \& Van Wassenhove, L. N. (2016), "Host government impact on th log stics performance of international humanitarian organisations", Journal of Jperations M-. lag - inent, Vol. 47-48 No., pp. 44-57.

Dud' $=$ y (2017), "TROUB E Ir. TABASCO; Flood relief efforts stall under the weight of political baggage; Bickering parties impeding supplies in some areas."

Eisenhardt, K. M. (1989), "Building Theories from Case Study Research", The Academy of Management Review, Vol. 14 No. 4, pp. 532-550.

Fisher, G., \& Aguinis, H. (2017), "Using Theory Elaboration to Make Theoretical Advancements", Organizational Research Methods, Vol. 20 No. 3, pp. 438-464.

Ford, J. D., \& Schellenberg, D. A. (1982), "Conceptual Issues of Linkage in the Assessment of Organizational Performance", The Academy of Management Review, Vol. 7 No. 1, pp. 49-58.

Garschagen, M. (2016), "Decentralizing urban disaster risk management in a centralized system? Agendas, actors and contentions in Vietnam", HABITAT INTERNATIONAL, Vol. 52 No. Supplement C, pp. 43-49.

Grünewald, F., Binder, A., \& Georges, Y. (2010), "Int . -asency real-time evaluation in Haiti: 3 months after the earthquake", working paper, Urgenr= Re' abilitation Developpment and Global Public Policy Institute, 31 August 2010.

Gupta, M. C. (1995), "Environmental management and it imp- ct on the operations function", International Journal of Operat:ol ; \& Production $\mathrm{N}$ an= enent, Vol. 15 No. 8, pp. 34-51.

Hart, P. t., Rosenthal, U., \& Kouzmin, A. (1993), "Crisis Decisio । M king", Administration \& Society, Vol. 25 No. 1, pp. 12-45.

Heaslip, G., \& Barber, E. (2014), "Using the military in disaster relief. systemising challenges and opportunities", Journal of Humanitarian Logistics and Supply Chain Management, Vol. 4 No. 1 , pp. 60-81.

Helena, F. (2007), "The impact of performance management on customers' expected logistics performance", International Journal of Operations \& Production Management, Vol. 27 No. 8, pp. 901-918.

Hernández, M. d. C. (2009), "Experiencias de las organizaciones civiles en el proceso de reconstrucción de las comunidades de Tabasco", working paper, Asociación Ecológica Santo Tomás A.C.,

Hilhorst, D., \& Schmiemann, N. (2002), "Humanitarian principles and organisational culture: Everyday practice in Meédecins Sans Frontié res-Holland", Development in Practice, Vol. 12 No. 3-4, pp. 490-500.

Holguin-Veras, J., Jaller, M., Van Wassenhove, L. N., Perez, N., \& Wachtendorf, T. (2012), "On the unique features of post-disaster humanitarian logistics", Journal of Operations Management, Vol. 30 No. 7-8, pp. 494-506.

Holguín-Veras, J., Jaller, M., \& Wachtendorf, T. (2012), "Comparative performance of alternative humanitarian logistic structures after the Port-au-Prince earthquake: ACEs, PIEs, and CANs", Transportation Research Part A: Policy and Practice, Vol. 46 No. 10, pp. 1623-1640.

Holguín-Veras, J., Pérez, N., Jaller, M., Van Wassenhove, L. N., \& Aros-Vera, F. (2013), "On the appropriate objective function for post-disaster humanitarian logistics models", Journal of Operations Management, Vol. 31 No. 5, pp. 262-280.

INEGI (2012) "Indicadores de Bienestar por entidad federativa", available at: http://www.beta.inegi.org.mx/app/bienestar/?ag=27\#grafica (accessed 3rd March 2017). 
J4 50 Ketokivi, M., \& Choi, T. (2014), "Renaissance of case research as a scientific method", Journal of 51 Operations Management, Vol. 32 No. 5, pp. 232-240. 
Khan, M. R. ^ Rahman, M. A. (2007), "Partnership approach to disaster management in Bangladesh: - uritical policy assessment", Natural Hazards, Vol. 41 No. 2, pp. 359-378.

Kovacs, G \& Sr ens, K. (2009), "Identifying challenges in humanitarian logistics", International Joli...al , Physical Distribution \& Logistics Management, Vol. 39 No. 6, pp. 506-528.

Kovacs, G., \& sper.s, k. M. (2011), "Trends and developments in humanitarian logistics - a gap analysis', '.tel,rational Journal of Physical Distribution \& Logistics Management, Vol. 41 No. 1, pp. 32-45

Kumar. '., Niedan-Oisf „, K., \& Peterson, L. (2009), "Educating the supply chain logistics for humanitarian $€$ for , in Africa: a case study", International Journal of Productivity and Performance Marıagement, Vol. 58 No. 5, pp. 480-500.

Kunz, N., Reiner, G., \& Gold, S. (2014), "Investing in disaster management capabilities versus prepositioning inventory: A new approach to disaster preparedness", International Journal of Production Economics, Vol. No., pp.

Lu, Y., \& Xu, J. (2015), "NGO collaboration in community post-disaster reconstruction: field research following the 2008 Wenchuan earthquake in China", Disasters, Vol. 39 No. 2, pp. 258-278.

MacCarthy, B. L., Blome, C., Olhager, J., Srai, J. S., \& Zhao, X. (2016), "Supply chain evolution -

Management, Vol. 36 No. 12, pp. 1696-1718.

Manyena, S. B. (2006), "Rural local authorities and disaster resilience in Zimbabwe", Disaster Prevention and Management: An International Journal, Vol. 15 No. 5, pp. 810-820.

Marks, J. L. (1978), On Decision-Making Processes and Structures, ERIC Clearinghouse, Washington D.C.

Marquez, L. M. M. (2016), "The Relevance of Organizational Structure to NGOs' Approaches to the Policy Process", Voluntas: International Journal of Voluntary and Nonprofit Organizations, Vol. No. 1, pp. 465.

Mileti, D. S., \& Sorensen, J. H. (1987), "Determinants of Organizational Effectiveness in Responding to Low Probability Catastrophic Events", Columbia Journal of World Business, Vol. 22 No. 1, pp. 13-21.

Nathan, K., Luk, N. V. W., Maria, B., Christophe, H., \& Gyöngyi, K. (2017), "Relevance of humanitarian logistics research: best practices and way forward", International Journal of Operations \& Production Management, Vol. 37 No. 11, pp. 1585-1599.

Nigg, J. M., Barnshaw, J., \& Torres, M. R. (2006), "Hurricane Katrina and the Flooding of New Orleans: Emergent Issues in Sheltering and Temporary Housing", The ANNALS of the American Academy of Political and Social Science, Vol. 604 No. 1, pp. 113-128.

strategies", Disaster Prevention \& Management, Vol. 14 No. 4, pp. 506-521.

Ordaz, M., \& Zeballos, A. (2007), INFORMACIÓN PARA LA GESTIÓN DE RIESGO DE DESASTRES ESTUDIO DE CASO DE CINCO PAÍSES: MÉXICO, CEPAL, México, D.F.

Parnell, J. A. (2015), "Crisis Management and Strategic Orientation in Small and Medium-Sized Enterprises (SMEs) in Peru, Mexico and the United States", Journal of Contingencies and Crisis Management, Vol. 23 No. 4, pp. 221-233.

Peter-Christian, P., \& Dmitrij, S. (2015), "Management of the learning curve: a case of overseas production capacity expansion", International Journal of Operations \& Production Management, Vol. 36 No. 1, pp. 42-60.

Quarantelli, E. L. (1988), "DISASTER CRISIS MANAGEMENT: A SUMMARY OF RESEARCH FINDINGS", Journal of Management Studies, Vol. 25 No. 4, pp. 373-385.

Ransikarbum, K., \& Mason, S. J. (2016), "Goal programming-based post-disaster decision making for integrated relief distribution and early-stage network restoration", International Journal of Production Economics, Vol. 182 No., pp. 324-341. 
J4 $50 \quad$ Richter, K.-F., Shi, M., Gan, H.-S., \& Winter, S. (2013), "Decentralized evacuation management", 51 Transportation Research Part C: Emerging Technologies, Vol. 31 No., pp. 1-17. 
Roshan Bhakta, B., Christine, O., \& Benjamin, B. (2014), "Organisational features and their effect on the perceived performance of emergency management organisations", Disaster Prevention and Management: An International Journal, Vol. 23 No. 3, pp. 222-242.

Ruffini, F., Duer 1., \& Riemsdijk, M. v. (2000), "Organisation design in operations management", Interr atir al Journal of Operations \& Production Management, Vol. 20 No. 7, pp. 860-879.

Saldana-Zorrilla, S , 20.5), "Assessment of disaster risk management in Mexico", Disaster Prevention and Manager.ent An International Journal, Vol. 24 No. 2, pp. 230-248.

Santos-r.eyes, J., Alvar- uo-_urona, R., \& Olmos-Peña, S. (2010), "Learning from Tabasco's floods by applying MORT , S- .ety Science, Vol. 48 No. 10, pp. 1351-1360.

Scolobig, A., Prior, T., Schröter, D., Jörin, J., \& Patt, A. (2015), "Towards people-centred approaches for effective disaster risk management: Balancing rhetoric with reality", International Journal of Disaster Risk Reduction, Vol. 12 No., pp. 202-212.

SEGOB (2012). ACUERDO que establece los Lineamientos del Fondo para la Atención de Emergencias FONDEN. (pp. 30).

Sienou, A., \& Karduck, A. P. Logistics challenges in developing countries: An analyis of Burkina Faso's national plan for disaster prevention and response. In Digital Ecosystems Technologies doi:10.1109/dest.2012.6227938.

Takeda, M., \& Helms, M. (2006), "“Bureaucracy, meet catastrophe”: Analysis of the tsunami disaster relief efforts and their implications for global emergency governance", International Journal of Public Sector Management, Vol. 19 No. 2, pp. 204-217.

Taylor, A., \& Taylor, M. (2009), "Operations management research: contemporary themes, trends and potential future directions", International Journal of Operations \& Production Management, Vol. 29 No. 12, pp. 1316-1340.

Thomas, A., \& Mizushima, M. (2005), "Logistics training: necessity or luxury?", Forced Migration Review, Vol. 22 No., pp. 60-61.

Thompson, D. D. P. (2015), "Disaster logistics in small island developing states: Caribbean perspective", Disaster Prevention and Management: An International Journal, Vol. 24 No. 2, pp. 166-184.

Tofighi, S., Torabi, S. A., \& Mansouri, S. A. (2016), "Humanitarian logistics network design under mixed uncertainty", European Journal of Operational Research, Vol. 250 No. 1, pp. 239-250.

Van Wassenhove, L. N. (2006), "Humanitarian Aid Logistics: Supply Chain Management in High Gear", The Journal of the Operational Research Society, Vol. No. 5, pp. 475.

Voss, C., Tsikriktsis, N., \& Frohlich, M. (2002), "Case research in operations management", International Journal of Operations \& Production Management, Vol. 22 No. 2, pp. 195-219.

of the Federal Emergency Management Agency following Hurricane Katrina", International Journal of Social Economics, Vol. 35 No. 7, pp. 501-511.

Whybark, D. C., Melnyk, S. A., Day, J., \& Davis, E. (2010), "Disaster Relief Supply Chain Management: New Realities, Management Challenges, Emerging Opportunities", Decision Line, Vol. 41 No. 3, pp. 4.

Wijngaard, J., Vries, J. d., \& Nauta, A. (2006), "Performers and performance: How to investigate the contribution of the operational network to operational performance", International Journal of Operations \& Production Management, Vol. 26 No. 4, pp. 394-411.

Yin, R. K. (1994), Case study research : design and methods, Sage. 
Table 1. Data collected about the case of Villahermosa

\begin{tabular}{|c|c|c|}
\hline Type of data & Source & FOI \\
\hline Shelters used & PC, ISSET & 700106513,06401914 \\
\hline Facility cleaning cost & DIF & 1236000003414 \\
\hline Distribution centres used & SEDENA, DICONSA & 700003414,2015000000714 \\
\hline Procurement per product & DICONSA & $\mathrm{R} 2015000008113$ \\
\hline $\begin{array}{l}\text { Required personnel per } \\
\text { activity }\end{array}$ & SEDENA, PC, IMSS, DICONSA & $\begin{array}{l}\text { 700003214, 00001514, 00430914, } 00432114, \\
64101320214,700004914,2015000010414\end{array}$ \\
\hline $\begin{array}{l}\text { Number of personnel per } \\
\text { activity per organisation }\end{array}$ & $\begin{array}{l}\text { DICONSA, DIF, IMSS, ISSET, PC, } \\
\text { SMEXICO, STABASCO, SCT, SEDENA, } \\
\text { SEGOB, SEMAR, SSP }\end{array}$ & $\begin{array}{l}2015000001314,2015000003814, \\
2015000004014,06399914,0064100438914, \\
06644914,06402614,06402714, \\
0001200006714,06400314,06243714, \\
0000700031014,0000700144314, \\
0000700106513,0000400264914, \text { Press release } \\
148 / 2007,05924314\end{array}$ \\
\hline $\begin{array}{l}\text { Total personnel per } \\
\text { agency }\end{array}$ & $\begin{array}{l}\text { DICONSA, DIF, IMSS, ISSET, PC, } \\
\text { SMEXICO, STABASCO, SCT, SEDENA, } \\
\text { SEGOB, SEMAR, SSP }\end{array}$ & $\begin{array}{l}2015000001314,2015000003814, \\
2015000004014,06399914,0064100438914, \\
06644914,06402614,06402714, \\
0001200006714,06400314,06243714, \\
0000700031014,0000700144314, \\
0000700106513,0000400264914, \text { Press release }\end{array}$ \\
\hline & & $148 / 2007,05924314$ \\
\hline Vehicles used & $\begin{array}{l}\text { CENTRO. DICONSA. DIF. IMSS. PC. } \\
\text { SMEXICO, STABASCO, SEDENA, } \\
\text { SEGOB, SEMAR, SSP } \\
\text { SEDENA }\end{array}$ & $\begin{array}{l}05923014,05923214,2015000001014, \\
2015000003714,2015000003914,06400114, \\
0064100439014,0064100439414,06402814, \\
0001200006814,05923814,05924014, \\
0000700002614,0000700031114, \\
0000700031314,0000700106513, \\
0000400264914, \text { Press release } 148 / 2007, \\
05924414\end{array}$ \\
\hline Medicines delivered & SEGOB & 0000400160314 \\
\hline Flood mask & CENAPRED & 0413000000214 \\
\hline $\begin{array}{l}\text { Technical reports of the } \\
\text { situation }\end{array}$ & SEMAR, CENAPRED & 0064100439014,0413000000514 \\
\hline International aid & SRE & 0000500088214 \\
\hline $\begin{array}{l}\text { Elevation models of the } \\
\text { region }\end{array}$ & \multicolumn{2}{|c|}{$\begin{array}{l}\text { United States Geological Survey (www.usgs.gov) and the website of the National Institute of } \\
\text { Geography and Statistics (INEGI) in Mexico (http://www.inegi.org.mx/) }\end{array}$} \\
\hline
\end{tabular}

Road network $\quad$ Software developed by INEGI, namely SCINCE 2010 (http://www.inegi.org.mx/)

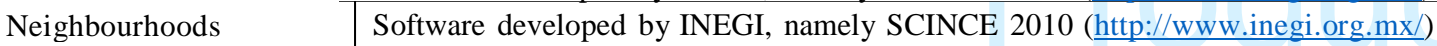
denominated Basic GeoStatistical Area (AGEBs)

Demographical data Resources from NGOs
Software developed by INEGI, namely SCINCE 2010 (http://www.inegi.org.mx/) Online reports from the Mexican Red Cross, Presbyterian Mission Agency, Action by 
Churches Together International, Aktion Deutschland Hilft, Samaritan's purse, Malteser, World Vision, Search and Rescue Assistance in Disasters, Medical Teams International, Adventist Development and Relief Agency, Americares and the World Food Programme. 